\title{
Students' Writing Research as a Tool for Learning - Insights into a Seminar with Research-Based Learning
}

\author{
Katrin Girgensohn \\ European University Viadrina, Germany
}

\begin{abstract}
Research-based learning is an approach that lets students conduct research to develop content knowledge. This article gives insights into a seminar that followed this approach. It was a collaboration between the writing center and the linguistics department at European University Viadrina in Germany with the aim to explore new ways of combining the learning of content knowledge and writing. In accordance with the stance of the Scholarship of Teaching and Learning (SOTL), this collaboration was meant to be a pilot to generate experiences and knowledge about this approach and its potential for combining discipline-specific learning and writing.
\end{abstract}

\section{Introduction}

University learning ${ }^{1}$ is usually based on research, as it should be grounded on the current state of research in the disciplines that students study. Thus, university seminars will more or less be linked to the teachers' own research or their knowledge of current research. Furthermore, characteristics of university learning include features that are similar to features of research, such as studying academic literature, developing critical questions or writing reports. This does not mean, however, that students necessarily participate in research themselves. Some approaches to university teaching therefore explicitly stress students' own research experiences. They use research as a tool for learning. There are different terms in use for this special approach to students' learning, such as inquiry-based learning (e.g. Healey 2005, Stephenson n.d.), enquiry-based learning (e.g. Kahn/O'Rourke 2005), collaborative inquiry learning (e.g. Bell/Urhahne/Schanze et al. 2010), research-based learning (e.g. Lambert 2009), or undergraduate research (cf. Kinkead 2012). The common characteristics of these pedagogical approaches to students' learning, which will be referred to as research-based learning subsequently ${ }^{2}$, include the following criteria:

Students are:

- tackling real-world questions, issues and controversies;

- developing questioning, research and communication skills;

\footnotetext{
${ }^{1}$ This article is based on my experience and understanding of the German university system, which is known for stressing the interdependence of research and teaching ("Einheit von Forschung und Lehre"). I assume, however, that this approach is important for many universities worldwide, because the German system was a model for the US-American university system (cf. Kinkead 2012, 24) and US-HigherEducation became a model for universities worldwide (cf. Meyer/Schofer 2007).

2 The German term that we referred to with our seminar concept is "Forschendes Lernen" (for a detailed concept and definition, cf. Reinmann 2015).
} 
- $\quad$ solving problems or creating solutions;

- collaborating within and beyond the classroom;

- developing deep understanding of content knowledge;

- participating in the public creation and improvement of ideas and knowledge (Stephenson n.d.).

Another main characteristic is that learning processes follow similar steps as the research process: exploring a topic through engaging in real-world issues and current research, identifying problems that lead to questions, finding an appropriate methodological approach, carrying out research (empirically or theoretically), discussing findings and finally contributing knowledge to a real audience. In consequence, research-based learning is open-ended and teachers serve more as facilitators than as lecturers. The group of learners, together with teachers, does not know where the learning and researching experience will end. As Reinmann (2015) underlines, it is hard to define very specific learning outcomes of content knowledge with this approach, but on the other hand research-based learning can be a promising way to deal with heterogeneous groups of learners because it allows individual approaches and leads students to detect their deficits on their own.

Many more advantages are attributed to research-based learning, like increasing motivation, fostering independent and deep learning and developing creativity and key-competences (Dostál 2015) - features that are desirable for classes on academic writing as well. So why not combine a research-based learning approach with learning academic writing at university? In the following, I present a case study of a seminar that was conducted as a trial for using the approach of research-based learning. The seminar was a co-teaching project between a writing center teacher and a university teacher of linguistics at European University Viadrina in Germany. The aim of this article is to give an impression of an innovative way to integrate disciplinary teaching and writing. I hope to encourage other teachers of writing to seek collaborations like the one presented here, which was a pilot and therefore has certain weak points that I will discuss in the conclusion. I will give a detailed picture of how we worked in the seminar and also sketch some of the results of the students' research in section 3. Before I come to this, I will first introduce the methodological approach for the case study in section 2. Finally, I will draw some conclusions for using the research-based learning approach as a mode for teaching writing in section 4.

\section{Methods}

For us, two co-teaching seminar teachers, conducting this seminar can be understood as an act of participation in the Scholarship of Teaching and Learning (SOTL): 'Anchored in inquiry and engagement, the scholarship of teaching and learning (SoTL) reconceptualizes teaching as an ongoing and scholarly process with an emphasis on improving student learning' (International Journal Scholarship of Teaching and Learning, n.d.). Our course of action qualifies as SOTL in the way Huber (2014) defines it:

- SOTL regards teaching as a field for inquiry in institutional settings and disciplines;

- It uses observations and irritations in teaching settings as starting points for experimenting with innovative approaches;

- It includes systematic investigations about the current state of research;

- It uses teaching for ongoing reflections and data-gathering;

- It aims at installing changes in the institutional setting;

- It participates in the creation of public knowledge through publishing.

The observations and irritations that led to the experiment resulted from an ongoing cooperation between both of us co-teachers. The linguist (co-teacher 1) had wanted to use writing as a tool for learning in her seminars and had therefore developed the idea of having her students write excerpts during the semester and provide each other with peer-feedback through an online platform. With 'excerpt' I refer to the term 'Exzerpt' used in Germany for a genre that condenses argumentative academic texts or parts of those through summarizing, paraphrasing and quoting. Excerpts should foster close reading, and generate reduced but thorough texts that can later be reused, e.g. for writing research articles. Writers of excerpts 
always need to indicate clearly that they restate other authors' thoughts. However, an excerpt can also include the writer's critical thoughts if indicated correctly (Moll 2002).

I, the writing center teacher (co-teacher 2), had counseled the process of developing this seminar concept and had provided workshops that introduced the students to the excerpt genre and to giving peerfeedback. After two semesters of this cooperation, we both had observed that using writing had enhanced the quality of class discussions, because students were better prepared. However, we wanted to know more: Did the quality of the students' writing also improve? This was hard to say, because there was no systematic investigation of the students' papers. We had the impression that there was improvement, but that a seminar that focused more explicitly on writing might enhance the students' writing competences even more. We therefore looked for a new way to teach discipline-specific content (linguistics in this case) with a focus on writing. That was the starting point for designing a seminar that followed the researchbased learning approach.

With regard to reflecting and data-gathering, our methodological approach was the following: during the semester when we held the seminar, we met on a weekly basis to talk about our experiences, reflect orally on our students' ongoing work and re-adjust the seminar plan. Furthermore, we designed a questionnaire in addition to our university's regular evaluation procedure. This questionnaire used openended questions to explicitly ask the students to reflect on the criteria of research-based learning mentioned above. It was filled out and discussed during our last seminar meeting. Afterwards, we transferred the answers into the MaxQDA software in order to conduct a content analysis. For this analysis, we used deductive categorizing to gain more detailed knowledge about students' perceptions. More specifically, we sorted the student answers into categories drawn from the criteria for researchbased learning and then drew generalized conclusions through comparing and reformulating the categories.

\section{Insights into the seminar}

In the following, I am going to describe the seminar setting that followed the research-based learning approach. To avoid confusions, I will use the term 'student-researchers' for those students that participated in this seminar and the term 'student-writers' for those students who had participated in the former seminars and contributed to the database used by the student-researchers. The overall idea of this seminar was that student-researchers conduct writing research to gain more knowledge about student-writers' writing on the one hand and to gain deep knowledge about linguistic research approaches on the other hand. Over the course of one semester, student-researchers followed a research-based learning process as sketched above that I will describe in more detail in this section. The data for the empirical research consisted of excerpts written by student-writers in the former seminars sketched above. ${ }^{3}$ The research results were meant to make a real contribution to the discourse community of writing research. Therefore, the group had to write a research paper that aimed at publication and that would give recommendations for using writing as a tool for learning.

\subsection{Seminar setting}

The Master-level seminar with the title 'Auf dem Weg zum perfekten Text?! Ein interdiziplinäres Forschungsseminar' (On the way toward a perfect text?! An interdisciplinary research seminar) took place in the winter semester of 2014/15. The description made it very clear that the seminar would include much independent research and writing work during the semester time. This is an unusual setting for German students in social sciences and humanities, because normally they do not have many research or writing tasks during the class periods and write their research papers in the class-free periods after the classes finish (see Foster 2002, MacGilchrist/Girgensohn 2011). This may have been the reason why only twelve student-researchers enrolled in this elective seminar, which was worth 9 European Credit

${ }^{3}$ All student-writers whose papers were included gave written permission for using their papers for research and for publishing these research results. 
Transfer System Points (ECTS) ${ }^{4}$ and, like all German seminars, would usually take place with two hours weekly over a period of 15 weeks. However, we changed this weekly routine as shown in the scheme below (Figure 1).
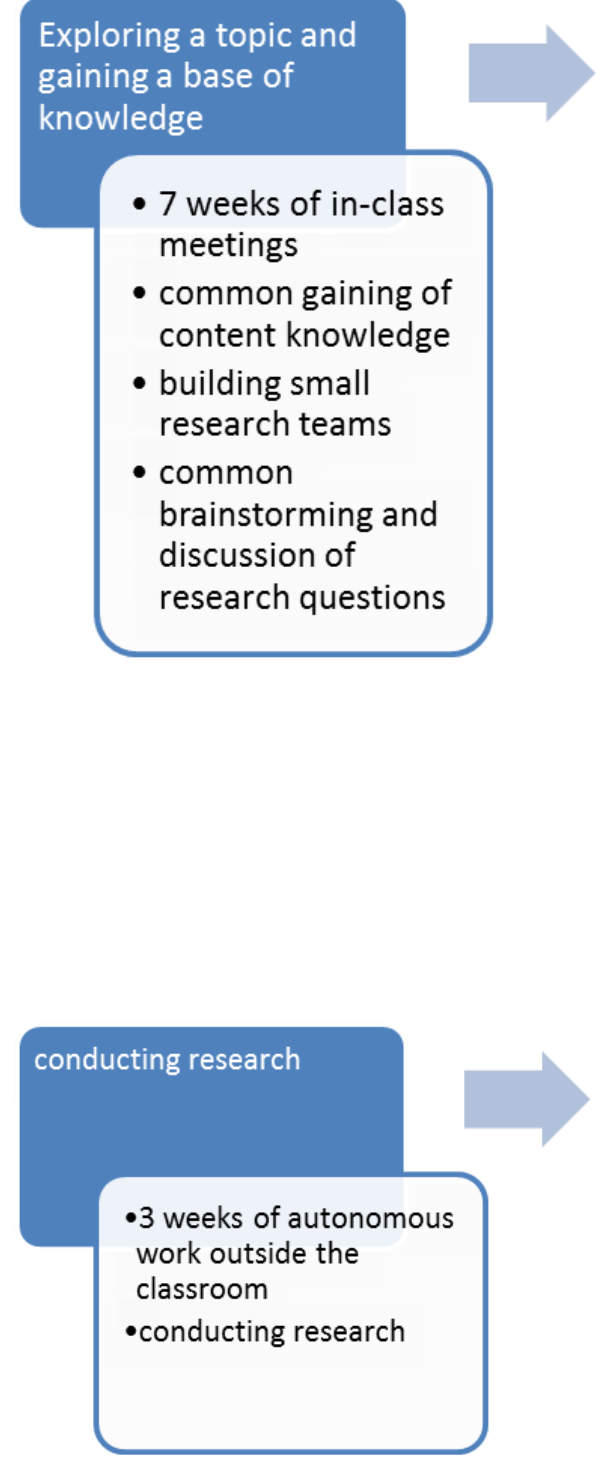
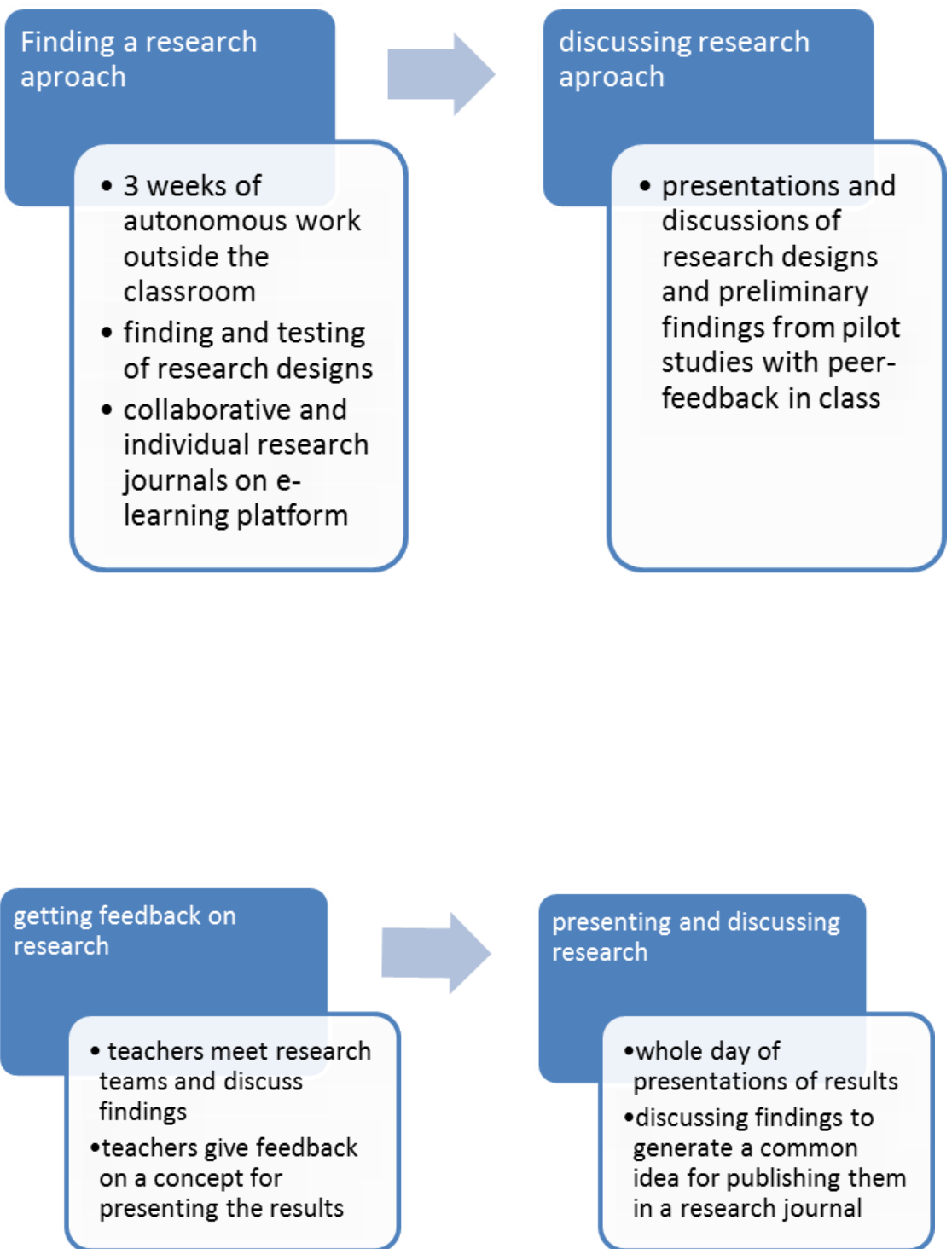

\footnotetext{
4 According to the Bologna Agreements, one ECTS means more or less 30 hours of work (http://ec.europa.eu/education/ects/ects en.htm).
} 

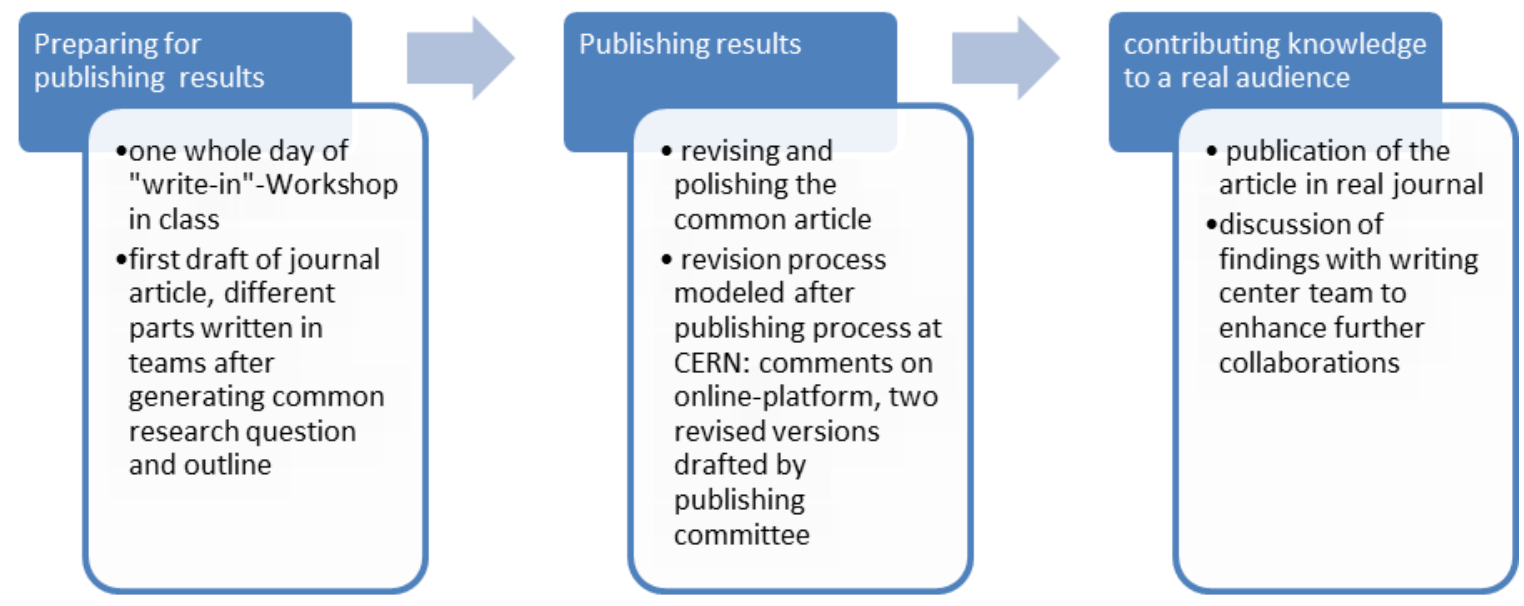

Figure 1: Flowchart of Seminar schedule throughout the semester

Seven weeks of in-class work were followed by three weeks of autonomous work in small research teams, one week of in-class presentations and then another three weeks of autonomous research, including individual consultations between teachers and research teams. Eventually, all research teams presented their results at a one-day conference, followed by intense discussions about overall conclusions that might be drawn from the different teams' findings. Another full day was then spent on drafting a first version of a common research article, written by all twelve student-researchers and two teachers collaboratively. We tried to model this writing process with such a large group of authors according to the publication processes of the ATLAS Collaboration of researchers at the European Organization for Nuclear Research (CERN) in Bern, as described by Graßhoff/Wütherich (2012) and Schefer (2012). This process includes several cycles of online writing, feedback and revision, using a common digital platform (etherpad in our case). This process finished with submitting the article to a real, blind peer-reviewed journal. The article was published half a year later after two more rounds of revision (AWPT-Forschungsgruppe 2015). The seminar itself closed with a meeting to evaluate the seminar and the learning processes during this semester, including an extended open-ended questionnaire that is the basis for the assumptions presented later in this article as described in the methods section above.

\subsection{Data and students' research}

As mentioned above, the first seven weeks of the seminar took place in class. They were dedicated to creating a common knowledge basis with regard to research processes and research methods. Studentresearchers had to explore different research approaches and present and explain them to their peers. They also read and discussed articles about writing didactics, writing research and about the genre 'excerpt'. Eventually, they brainstormed research questions that would fit the database that they had for their research. This database includes the following texts:

- 45 excerpts, written by 15 student-writers from two different seminars in linguistics, each excerpt in original and revised version;

- written feedback provided by peers for each excerpt's first version (provided during the seminars on an electronic learning platform called Moodle); 
- the original academic texts based on which those excerpt were written (four different articles);

- student-writers' written self-reflections on writing and revision processes (the student-writers had to hand in the original and the revised versions together with a written reflection on their writing and revising processes throughout the semester in a portfolio to get a final mark).

Student-researchers then formed four small research teams, based on different research questions they had found and on preferences for different methodical approaches. The following table gives an overview of the teams' research designs.

Table 1. Disciplinary Semiotic Domain Characteristics

\begin{tabular}{|c|c|c|c|}
\hline & Overall research questions & Methods & $\begin{array}{l}\text { Data-base (all samples } \\
\text { chosen randomly) }\end{array}$ \\
\hline Team 1 & $\begin{array}{l}\text { Did the excerpts improve through } \\
\text { revision with regard mainly to form } \\
\text { and structure? }\end{array}$ & $\begin{array}{l}\text { A rating task (without raters } \\
\text { knowing which was draft } 1 \\
\text { and draft 2) } \\
\text { (Rating criteria based on } \\
\text { Langer/Schulz von Thun } \\
2011 \text {, Becker- } \\
\text { Mrotzek/Böttcher 2006; } \\
\text { Nussbaumer/Sieber 1994; } \\
\text { Sieber 2008) }\end{array}$ & $\begin{array}{l}\text { Excerpts from } 10 \\
\text { writers (each of them } \\
\text { one excerpt in original } \\
\text { and revised version) }\end{array}$ \\
\hline Team 2 & $\begin{array}{l}\text { What do student-writers revise and } \\
\text { how? }\end{array}$ & $\begin{array}{l}\text { Qualitative data analysis } \\
\text { (Mayring 2008, categories } \\
\text { based on Becker-Mrotzek } \\
\text { 2006; Nussbaumer \& } \\
\text { Sieber 1994; Sieber 2008) }\end{array}$ & $\begin{array}{l}\text { Excerpts from three } \\
\text { writers (each writer } \\
\text { three excerpts in } \\
\text { original and revised } \\
\text { version, plus feedback } \\
\text { comments) }\end{array}$ \\
\hline Team 3 & $\begin{array}{l}\text { Did the excerpts improve through } \\
\text { revision with regard mainly to } \\
\text { content? }\end{array}$ & $\begin{array}{l}\text { Qualitative data analysis } \\
\text { (Schreier 2014, categories } \\
\text { based on Baurmann 2006) }\end{array}$ & $\begin{array}{l}\text { Excerpts from two } \\
\text { writers (each writer } \\
\text { three excerpts in } \\
\text { original and revised } \\
\text { version plus the original } \\
\text { academic texts based } \\
\text { on which those excerpts } \\
\text { were written) }\end{array}$ \\
\hline Team 4 & $\begin{array}{l}\text { Which concepts and metaphors do } \\
\text { students use to describe a good } \\
\text { excerpt and how to achieve it? }\end{array}$ & $\begin{array}{l}\text { Metaphor-analysis } \\
\text { (Cameron/Maslen 2010), } \\
\text { selection based on Kellogg } \\
\text { 2008) }\end{array}$ & $\begin{array}{l}32 \text { Feedback-Texts with } \\
300 \text { Metaphors }\end{array}$ \\
\hline
\end{tabular}

As shown in the table, the teams had different research questions, used different methods and different texts as data. The teams had developed those research designs independently, but discussed them in class before starting the research. Each team started with a pilot study to test and re-adjust the research design. Results of those pilot studies were presented and discussed in class again. The final results were presented and discussed during a class conference with the aim to draw common conclusions. Those common conclusions will be introduced in the next section.

\subsection{Student-researchers' research results}

The following are the results of the in class-discussion, which had aimed at finding common ground and at generalizing the findings of the different research teams. For a more detailed presentation of the findings of the projects, see AWPT-Forschungsgruppe (2015).

Overall, student-researchers found that the excerpts had improved through peer-feedback and revision. However, according to the findings, the texts did not improve overall to a great extent. Furthermore, the 
improvements often were not stable: student-writers did improve certain things only once, but not throughout the whole text, implying that they would conduct the same error later on again.

The metaphors that the feedback givers used also show that the student-writers seem to have a conceptual and theoretical knowledge about the excerpt genre; nevertheless they could not always transfer this knowledge to their own writing. Student-writers struggled especially with author references. They did not indicate paraphrases and often did not make it clear that they were restating other authors' thoughts. Furthermore, student-writers had only a small distance from the original text with regard to the original text's structure. They very rarely found their own structure to summarize the original texts.

Overall, the research teams found the quality of the revised excerpts to be below their expectations. This is an interesting finding, because the research teams turned out to be much more critical than the peer feedback givers in the classes had been. The research-based and methodological examination of their peers' texts allowed the research teams to gain a deeper understanding of the quality of texts and their revisions. This led them to the conclusion the writing-intensive classes had been a good starting point to gain writing competencies, but that more support would be needed to make the classes more effective. Particularly, it became obvious to the student-researchers that the student-writers in former seminars lacked an understanding of revision processes. The student-writers had not known how to transfer their peers' feedback effectively into revision. As already shown by Nancy Sommers (1994 (1980)), the novice writers' revision was more a polishing of surface matters than a rewriting process. Based on their research findings, the student-researchers recommended that more intensive writing classes are needed and that those classes need to dedicate more time to explicitly working on writing competences and on revision practice. This means that teachers of those classes would need to agree on reducing content in order to increase the amount of explicit writing and revision training.

\subsection{Student-researchers' seminar evaluation: What did they learn?}

With regard to the inquiry-based learning approach some conclusions can be drawn from the studentresearchers' evaluation, based on their written answers to an open-ended questionnaire.

Student-researchers perceived the tackling of real-world questions, issues and controversies as highly motivating. The opportunity to develop individual research questions was especially intriguing. For many of them, it was their first time conducting real research. Therefore, they experienced the input and guidance as very important. They enjoyed getting to know different research methods and gained awareness of the possible pitfalls of empirical research. The experiences were seen as a good preparation for future research, e.g. the Master thesis, but also after university.

It was important for the student-researchers to know that they need to find answers and solutions that matter. The goal-orientation throughout the seminar was perceived as helpful for finding solutions. It fostered personal responsibility and also creativity and reflective learning. Furthermore, they appreciated getting and giving feedback.

With regard to collaborating within and beyond the classroom, student-researchers said that the autonomous group work was 'surprisingly good'. This may be because we had dedicated some time to defining rules within the research teams and to negotiating milestones. However, they would have appreciated more exchange between research teams. The research diary we wanted them to write was not perceived as useful, probably because it did not have an audience beyond us teachers. Overall, student-researchers found the collaboration aspect of the seminar to be a good preparation for future jobs.

The possibility to participate in the public creation of knowledge through writing an article that was intended to be published was experienced as highly motivating. The collaborative writing process was seen as a significant experience for future professional contexts. However, student-researchers experienced the production of an article within such a short time period as very challenging and wished they would have had more time for this process. Also, at this point they would have valued more guidance. Many student-researchers stated that the whole process would have been much easier if there 
had been a common research question for all teams, although on the other hand they had enjoyed developing their own research questions.

With regard to learning outcomes it can be said that student-researchers' views on the development of deep learning and content knowledge were ambiguous. Some students had the impression that they learned less than in other seminars and that the content had been 'too vague', while others experienced their learning as deeper than in other seminars and even found content 'too much and too intense'. Consequently, some students thought the seven weeks in the beginning were too much time to prepare for the research tasks while others would have wanted more time. Overall, student-researchers recognized that content learning seemed to be less structured than in other seminars, because they had to find their own pathways over long periods. The most intensive learning happened with regard to research methods and within the students' own research projects.

With regard to learning writing it can be clearly stated that students gained a deeper understanding of text quality and of revision processes through conducting their own research projects. As shown above, they became more critical with regard to text quality and understood that surface polishing seldom leads to the intended improvements. It can only be guessed whether this experience and knowledge will lead them to improve the quality of their own writing and of their own revision processes. However, being more conscious about writing is at least a first step.

In total, the evaluation was very positive, although students had to put much more time and effort into this class than they did in many others.

\section{Conclusion: Research-based learning as a way to integrate disciplinary content learning and writing}

The seminar concept that I introduced here was a pilot project for our writing center to try new ways in our collaboration with faculty and in our approaches to facilitate academic writing. As already said, we can only guess the outcomes with regard to the student-researchers' writing competences, because their own writing development was not in the focus. However, it is very likely that gaining a deep and criteria-based understanding of text quality will help them in their own future writing projects. For example, the research team that used text rating as method realized how difficult it can be to agree on criteria for 'good texts' when they designed the text grading rubric for their research. They had intensive discussions about the importance of surface-errors (such as spelling, punctuation, grammar) in relation to problems of text structure. Just this little step of developing a grading rubric and testing it - and becoming aware of how different the team members' understandings were - made them think of academic writing from new perspectives.

Nevertheless, talking about writing, researching writing and gaining a better understanding of writing will certainly raise awareness, but writing competences can, like all competences, only be built through practice. Therefore, it was very important for the student-researchers to write an article as a last step of the seminar. For nearly all of them it was the first time to actually publish research. As Masters students, all of them were familiar with the research paper genre, but most of them had never written an authentic article that was really meant to contribute knowledge to an academic community. They had to become familiar with the citation guidelines, find an appropriate style, estimate the audience and fit the article to the allowed word count - a real challenge, given that the results from four research teams needed to be built in. This experience was important and meaningful to the student-researchers. The whole setting was what Gerd Bräuer and Kirsten Schindler call an 'authentic writing arrangement' (Bräuer/Schindler 2011). They even experienced the challenging task of writing a text with 14 authors as authentic, because the writing process was modeled after the real writing processes of researchers at the CERN. The studentresearchers' evaluation comments with regard to the publication process indicate clearly that writing and publishing the results of the research was very important for them. 
In contrast, the task to write a team research diary was not conceived as helpful. Writing as a tool for the research process was not experienced as authentic, because it was a typical 'teacher-task'. It did not seem to be necessary for the research processes, because the teams worked very closely together and had many oral discussions. They did not see the need to write their personal thoughts about their research down, only to let the teachers participate. They would have been interested to have more exchange with the other research teams, though. Consequently, maybe writing research blogs, addressed to the other research teams with the authentic purpose to learn more about the other teams' research processes, would have been an opportunity to introduce writing as a useful tool for researching beyond the publication of results.

In conclusion, our pilot project showed us that research-based learning is a promising way to combine disciplinary content learning with learning to write. In this case, of course, it was a very suitable combination, because the field of linguistics includes research on writing. Therefore, the research content itself helped students to develop their own, criteria-based and deep understanding of writing. Having students examine other students' writing will not be a way to develop content knowledge in other disciplines, such as, for instance, politics or sciences. However, the criterion 'participating in the public creation and improvement of ideas and knowledge' is an essential part of research-based learning. This criterion is a great opportunity to combine content learning and learning to write. Having authentic writing tasks proved to be very stimulating and motivating. As the evaluation shows, student-researchers see the need to dedicate more time to this part of research-based learning. One way to gain more time might be to stretch one seminar over two semesters, so that the first could be dedicated to the research steps and the second to the publishing process. Another way might be to use less challenging genres and ask student-researchers to publish results in blog articles or produce podcasts. Also, it would have been easier if every research team had produced their own article, because fitting all results into one article and writing with a team of 14 authors was an additional challenge. On the other hand, studentresearchers found this experience to be especially authentic and helpful in preparing them for future job experiences.

Overall, our experience showed as that the approach of research-based learning opens new ways to integrating writing and content learning. Therefore, as a result of the collaboration, our writing center engaged in processes of reforming the BA program in cultural studies at our university in a way that research-based learning seminars will become an explicit part of the curricula.

Additionally, the research results of our student-researchers helped us to gain a deeper understanding of the intensive writing seminar that we had developed together with the linguist. Consequently, in future we will be aware that intensive writing classes need to dedicate more time to training writing and that we need to find ways to help students understand writing as rewriting. 


\section{References}

AWPT-Forschungsgruppe (2015) 'Mit Überarbeitung zum perfekten Text - aber wie? Eine Analyse zur Qualitätsverbesserung studentischer Exzerpte im Kontext eines schreibintensiven Seminars. ' Zeitschrift Schreiben online (14.09.2015), 1-8

Baurmann, J. (2006) Schreiben Überarbeiten Beurteilen. Ein Arbeitsbuch zur Schreibdidaktik. 2. ed. Seelze: Klett Kallmeyer

Becker-Mrotzek, M., Böttcher, I. (2006) Schreibkompetenz entwickeln und beurteilen. Praxishandbuch für die Sekundarstufe I und II. Berlin: Cornelsen Scriptor

Bell, T. et al. (2010) 'Collaborative Inquiry Learning: Models, tools, and challenges'. International Journal of Science Education 32 (3), 349-377

Bräuer, G., Schindler, K. (2011) 'Authentische Schreibaufgaben - ein Kozept'. in Schreibarrangements für Schule, Hochschule, Beruf. Freiburg im Breisgau: Fillibach, 12-63

Cameron, L., Maslen, R. (Hrsg.) (2010) Metaphor Analysis. Research Practice in Applied Linguistics, Social Sciences and the Humanities. London: Equinox

Dostál, J. (2015) Inquiry-based Instruction. Concept, Essence, Importance and Contribution. Olomouc: Palacky University, Faculty of Education

Foster, D. (2002) 'Making the Transition to University: Student Writers in Germany'. in Writing and Learning in Cross-National Perspective - Transitions from Secondary to Higher Education. Urbana, III: National Council of Teachers of English, 192-241

Graßhoff, G., Wütherich, A. (2012) MetaATLAS. Studien zur Generierung, Validierung und Kommunikation von Wissen in einer modernen Forschungskollaboration. Bern: Bern Studies in the History and Philosophy of Science

Healey, M. (2005) 'Linking Research and Teaching: Exploring Disciplinary Spaces and the Role of Inquiry-based Learning'. in Reshaping the University: New Relationships between Research, Scholarship and Teaching. McGraw Hill: Open University Press, 67-78

Huber, L. (2014) 'Scholarship of Teaching and Learning: Konzept, Geschichte, Formen, Entwicklungsaufgaben'. in Forschendes Lehren im eigenen Fach. Scholarship of Teaching and Learning in Beispielen. Bielefeld: WBV, 19-36

International Journal Scholarship of Teaching and Learning (o.j.) Thoughts on SoTL [online] available from <http://digitalcommons.georgiasouthern.edu/ij-sotl/scholarship.html> [14.04.2016]

Kahn, P., O'Rourke, K. (2005) 'Understanding Enquiry-based Learning'. in Handbook of Enquiry and Problem-based Learning. Irish Case Studies and International Perspectives. Galway: All Ireland Society for Higher Education, 1-12

Kellogg, R. T. (2008) 'Training Writing Skills: A Cognitive Developmental Perspective'. Journal of Writing Research I (1), 1-26

Kinkead, J. (2012) 'What's in a Name? A Brief History on Undergraduate Research' CUR on the Web 33 (1), 20-29 
Lambert, C. (2009) 'Pedagogies of Participation in Higher Education: A Case for Research-based Learning'. Pedagogy, Culture \& Society 17 (3), 295-309

Langer, I., Schulz von Thun, F. (2011) Sich verständlich ausdrücken. München: Reinhardt

MacGilchrist, F., Girgensohn, K. (2011) 'Humboldt meets Bologna. Developments and debates in institutional writing support in Germany'. Canadian Journal for Studies in Discourse and Writing $23(1)$

Mayring, P. (2008) Qualitative Inhaltsanalyse. Grundlagen und Techniken. 10. ed. Weinheim: Beltz Verlag

Meyer, J. W., Schofer, E. (2007) 'The University in Europe and the World: Twentieth Century Expansion' in Towards a Multiversity? Universities between Global Trends and National Traditions. Bielefeld: transcript, 45-62

Moll, M. (2002) '"Exzerpieren statt fotokopieren" - Das Exzerpt als zusammenfassende Verschriftlichung eines wissenschaftlichen Textes'. in "Effektiv studieren" Texte und Diskurse in der Universität. OBST Beiheft Osnabrücker Beiträge zur Sprachtheorie 12,104-126

Nussbaumer, M., Sieber, P. (1994) 'Texte analysieren mit dem Zürcher Textanalyseraster'. in Sprachfähigkeiten - Besser als ihr Ruf und nötiger denn je! Ergebnisse und Folgerungen aus einem Forschungsprojekt. Aarau: Verlag Sauerländer, 141-186

Reinmann, G. (2015) 'Heterogenität und Forschendes Lernen: Hochschuldidaktische Möglichkeiten und Grenzen'. in Gestaltungsraum Hochschullehre. Potenziale nicht-traditionell Studierender nutzen. Babara Budrich, 121-137

Schefer, M. (2012) 'Der Wissenbegriff am Limit? Kollaborative Wissensgenerierung im Grossforschungsprojekt ATLAS am CERN'. in MetaATLAS - Studien zur Generierung, Validierung und Kommunikation von Wissen in einer modernen Forschungskollaboration. Bern: Bern Studies in the History and Philosophy of Science, 83-212

Schreier, M. (2014) 'Varianten qualitativer Inhaltsanalyse: Ein Wegweiser im Dickicht der Begrifflichkeiten'. Forum Qualitative Sozialforschung / Forum: Qualitative Social Research 15 (1, Art.18), 59 Absätze

Sieber, P. (2008) 'Kriterien der Textbewertung am Beispiel Parlando'. in Textlinguistik - 15 Einführungen Tübingen: Narr Verlag, 271-289

Sommers, N. (1994 (1980)) 'Revision Strategies of Student Writers and Experienced Adult Writers'. in Landmark Essays on Writing Process Davis, CA: Hermagoras Press, 75-84

Stephenson, N. (n.d.) Introduction to Inquiry Based Learning [online] available from $<$ http://www.teachinquiry.com/index/Introduction.html > [27.12.2014] 